\title{
THE EFFECT OF BCAA ON ISOMETRIC FORCE FOLLOWING ENDURANCE EXERCISE IN A HOT ENVIRONMENT
}

\author{
EFEITO DOS AACR NA FORÇA ISOMÉTRICA APÓS EXERCÍCIO DE ENDURANCE EM UM \\ AMBIENTEQUENTE

\begin{abstract}
EFECTO DE LOS AACR EN LA FUERZA ISOMÉTRICA DESPUÉS DE EJERCICIO DE ENDURANCE EN UNAMBIENTECÁLIDO
\end{abstract}

Original Article

Artigo OrigINAL

Artículo Original

\begin{abstract}
Michele Macedo Moraes ${ }^{1}$ (Physical Education Professional) Reinaldo Teles Paulinelli-Júnior ${ }^{1}$ (Physical Education Professional) Francisco Teixeira-Coelho ${ }^{1,2}$ (Physical Education Professional) Gustavo Henrique da Cunha Peixoto Cançado ${ }^{1}$ (Physical Education Professional and Physiotherapist)

Samuel Penna Wanner ${ }^{1}$ (Physical Education Professional) Mauro Heleno Chagas' (Physical Education Professional) Danusa Dias Soares ${ }^{1}$ (Physical Education Professional)

1. Universidade Federal de Minas Gerais, Belo Horizonte, MG, Brazil. 2. Universidade Federal do Triângulo Mineiro, Uberaba, MG, Brazil.
\end{abstract}

\section{Correspondence:}

Michele Macedo Moraes. Av. Antônio Carlos, 6627, Belo Horizonte, MG, Brazil. 31.270-901.

michelemmoraes@ufmg.br

\begin{abstract}
Introduction: Fatigue due to endurance exercise results from both peripheral and central changes, and may influence subsequent performance during a strength task. The increase in serotonin concentration is one of the central factors associated with endurance exercise-induced fatigue, particularly in hot environments. A nutritional strategy employed to reduce serotonergic activation is supplementation with branched-chain amino acids (BCAA). Objective: To investigate whether BCAA supplementation attenuates the reduction in isometric force caused by prior endurance exercise in a hot environment. Methods: Nine volunteers (aged 25.4 \pm 1.2 years) performed a 2-min maximal voluntary isometric contraction ( $\mathrm{MVC}_{150}$ ) of upper limb muscles before and after an endurance exercise on a cycle ergometer at $40 \%$ of the maximal aerobic power. The volunteers underwent three experimental trials: 1) endurance exercise in a temperate environment $\left(23^{\circ} \mathrm{C}\right.$ and $\left.60 \% \mathrm{RH}\right)$; exercise in a hot environment $\left(35^{\circ} \mathrm{C}\right.$ and $\left.60 \% \mathrm{RH}\right)$ with the ingestion of: 2 ) a placebo solution or 3 ) a solution containing BCAA $30 \mathrm{mg} \cdot \mathrm{kg}^{-1}$. During the $\mathrm{MVC}_{\text {iso }}$ test, the isometric force of flexor muscles of the right elbow, core body temperature ( $\left.T_{\text {CORE }}\right)$ and heart rate (HR) were measured. Results: Isometric force decreased following endurance exercise in the hot environment, and BCAA administration did not attenuate this reduction. Greater $T_{\text {CORE }}$ and $H R$ values were observed following endurance exercise in the heat, compared to pre-exercise values, and supplementation did not interfere with these physiological responses. Conclusion: The reduction in isometric force, caused by previous endurance exercise in a hot environment, was not diminished by supplementation with BCAA. Level of evidence l; Type of study: Therapeutic studies - Investigation of treatment outcomes.
\end{abstract}

Keywords: Body temperature regulation; Fatigue; Isoleucine; Leucine; Physical endurance; Valine.

\section{RESUMO}

Introdução: A fadiga decorrente de um exercício de endurance ocorre devido a alterações tanto periféricas quanto centrais e pode influenciar no desempenho subsequente durante um teste de força. Sabe-se que o aumento da concentração de serotonina é um dos fatores centrais associados à fadiga induzida pelo exercício de endurance, principalmente em ambientes quentes. Uma estratégia nutricional utilizada para diminuir a ativação serotonérgica é a suplementação com aminoácidos de cadeia ramificada (AACR). Objetivo: Investigar se a suplementação com AACR atenua a redução da força isométrica causada pela realização prévia de um exercício de endurance em ambiente quente. Métodos: Nove voluntários (25,4 $\pm 1,2$ anos) realizaram uma contração voluntária máxima isométrica $\left(C V M_{15}\right)$ de membro superior durante 2 min, antes e após um exercício de endurance em um cicloergômetro a 40\% da potência máxima aeróbica. Os voluntários foram submetidos a três situações experimentais: 1) exercício de endurance em ambiente temperado $\left(23^{\circ} \mathrm{C}\right.$ e $60 \%$ URA); exercício em ambiente quente $\left(35^{\circ} \mathrm{C} ; 60 \%\right.$ URA) com ingestão de: 2) solução placebo ou 3) solução contendo $30 \mathrm{mg}^{\mathrm{kg} \mathrm{g}^{-1}}$ de AACR. Durante o teste de $C V M_{15 a}$ a força isométrica dos músculos flexores do cotovelo direito, a temperatura corporal interna ( $\left.T_{\mathbb{N}_{T}}\right)$ e a frequência cardíaca (FC) foram medidas. Resultados: A força isométrica diminuiu após o exercício de endurance no ambiente quente e a administração de AACR não atenuou essa redução. Valores maiores de $T_{\text {INT }}$ e FC foram observados após o exercício de endurance em ambiente quente em relação aos valores do pré-exercício, sendo que a suplementação também não interferiu nessas respostas fisiológicas. Conclusão: A redução da força isométrica, devido à realização prévia de exercício de endurance em ambiente quente, não foi atenuada pela suplementação com AACR. Nível de evidência l; Tipo de estudo: Estudos terapêuticos - Investigação dos resultados do tratamento.

Descritores: Regulação da temperatura corporal; Fadiga; Isoleucina; Leucina; Resistência física; Valina.

\section{RESUMEN}

Introducción: La fatiga derivada de un ejercicio de endurance ocurre debido a las alteraciones tanto periféricas como centrales y puede influir en el desempeño subsiguiente durante un test de fuerza. Se sabe que el aumento de la concentración de serotonina es uno de los factores centrales asociados a la fatiga inducida por el ejercicio de endurance, principalmente en ambientes cálidos. Una estrategia nutricional empleada para disminuir la activación serotonérgica es la suplementación con aminoácidos de cadena ramificada (AACR). Objetivo: Investigar si 
la suplementación con AACR atenúa la reducción de la fuerza isométrica causada por la realización previa de un ejercicio de endurance en ambiente cálido. Métodos: Nueve voluntarios (25,4 + 1,2 años) realizaron una contracción voluntaria máxima isométrica $\left(C V M_{150}\right)$ de dos minutos de miembro superior, antes y después de un ejercicio de endurance en un cicloergómetro a 40\% de la potencia máxima aeróbica. Los voluntarios fueron sometidos a tres situaciones experimentales: 1) ejercicio de endurance en ambiente templado $\left(23^{\circ} \mathrm{Cy} 60 \% \mathrm{HR}\right)$; ejercicio en ambiente cálido $\left(35^{\circ} \mathrm{C}, 60 \% \mathrm{HR}\right)$ con ingestión de: 2) solución placebo o 3) solución conteniendo $30 \mathrm{mg} \cdot \mathrm{kg}^{-1}$ de AACR. Durante el test de CVM 1 so, se midieron la fuerza isométrica de los músculos flexores del codo derecho, la temperatura corporal interna ( $T_{I_{N T}}$ y la frecuencia cardíaca (FC). Resultados: La fuerza isométrica disminuyó después del ejercicio de endurance en el ambiente cálido y la administración de AACR no atenuó esa reducción. Se observaron mayores valores de $T_{\text {INT }}$ FCC después del ejercicio de endurance en ambiente cálido con relación a los valores del pre ejercicio, siendo que la suplementación tampoco interfirió en estas respuestas fisiológicas. Conclusión: La reducción de la fuerza isométrica, debido a la realización previa de ejercicio de endurance en ambiente cálido, no fue atenuada por la suplementación con AACR. Nivel de evidencia I; Tipo de estudio: Estudios terapéuticos - Investigación de los resultados del tratamiento.

Descriptores: Regulación de la temperatura corporal; Fatiga; Isoleucina; Leucina; Resistencia física; Valina.

\section{INTRODUCTION}

From his own observations about the effects of running on reducing his strength performance, Robert Hickson was the first researcher to study the so-called 'concurrent training'. Since then, several studies have shown the effect of long-term aerobic (endurance) exercise (i.e., 21 to $160 \mathrm{~min}$ ) on the reduction of force production. 2-5 $^{-5}$

Interference from endurance exercise over force production occurs due to chronic responses - such as inhibition of hypertrophy signaling pathways ${ }^{1,2}$ - and acute responses caused by fatigue. ${ }^{2-4}$ One of the acute influences is the increase in core body temperature ( $\left.T_{\text {CORE }}\right)$. Nybo and Nielsen $(2001)^{5}$ showed that exercising on a cycle ergometer at 60\% of the maximal oxygen consumption $\left(\mathrm{VO}_{2 \max }\right)$ in a hot environment promoted greater reduction in force during a subsequent 2-min maximal isometric voluntary contraction ( $\mathrm{MVC}_{150}$ ) of upper-limb muscles, relative to the trial performed in a temperate environment. This exacerbated reduction in force was accompanied by greater reduction in central activation and, therefore, attributed to central mechanisms of fatigue dependent on a rise in $\mathrm{T}_{\text {CORE. }}{ }^{6,7}$

Increased serotonin (5-HT) concentration in the central nervous system (CNS) is a factor associated with the $T_{\text {CORE }}$ increase and fatigue during endurance exercise and, therefore, is a possible explanation for the subsequent reduction in strength performance. According to the central fatigue hypothesis, ${ }^{8,9}$ increased 5 -HT activity during endurance exercise can cause fatigue by inducing lethargy, increasing the rating of perceived exertion and reducing motivation, tolerance to pain/discomfort and central drive to the active musculature. 10,11

The 5-HT synthesis in the CNS depends on the passage of its precursor, free tryptophan (TRP free; not bound to albumin), through the blood-brain barrier, which is mediated by the L-carrier system. During endurance exercise, there is an increase in $5-\mathrm{HT}$ concentration in the CNS resulting from: (1) the release of free fatty acids (FFA) that have a greater affinity for albumin binding than TRP, thereby increasing the concentration of TRP free; and the oxidation of branched-chain amino acids (BCAA: leucine, isoleucine and valine), which compete with TRP free for the L-carrier system. ${ }^{9}$ In a hot environment, the 5-HT increase during endurance exercise is exacerbated by the greater stimulus for lipolysis and the greater sympathetic activation, both of which result in increased FFA and TRP free $^{12}{ }^{12}$ Thus, the 5-HT concentration is directly correlated with $T_{\text {CORE }}$ under these conditions. $9,13,14$

BCAA supplementation is a nutritional strategy to reduce the entry of TRP into the CNS to delay fatigue, ${ }^{11,12}$ since these amino acids compete with TRP for the same transport system. Considering that nutrition generally provides a small but potentially valuable contribution to performance in elite athletes, and that the use of supplements is widely diffused at all levels of sport, ${ }^{15}$ the aim of this study was to evaluate whether an acute supplementation with BCAA attenuates the reduction in isometric force caused by prior endurance exercise performed in a hot environment. Based on the central fatigue hypothesis, we suggested that supplementation would reduce 5 -HT brain synthesis and, therefore, would attenuate the reduction in force commonly observed following endurance exercise in a hot environment.

\section{METHOD}

\section{Participants and ethical care}

Nine physically active, non-smoking, male volunteers agreed to participate in the study and signed an informed consent form. The experimental procedures were approved by the Research Ethics Committee of the Universidade Federal de Minas Gerais (protocol 144/05) and respected the norms established by the National Health Council (Resolution 466/2012) and the Declaration of Helsinki (1965) regarding ethical principles involving human research. (Table 1)

\section{Guidance provided to volunteers}

Each volunteer was instructed to: 1) not use medications or supplements while participating in this research;2) refrain from drinking alcohol, caffeine, and from exercising $48 \mathrm{~h}$ prior to any data collection; 3 ) register their food intake during the $48 \mathrm{~h}$ prior to the first experimental trial, and to reproduce the same intake before the other trials.

\section{Experimental design}

The volunteers completed four visits to the laboratory. During the first visit, which took place 2-8 days before the beginning of the experimental trials, subjects were characterized and familiarized with the MVC ${ }_{150}$ task, and an incremental test was performed. On the experimental days, the volunteers performed $\mathrm{MVC}_{150}$ before and after endurance exercise on a cycloergometer ( $40 \%$ peak power at $50 \mathrm{rpm}$ ) until voluntary interruption of effort $(\sim 2 \mathrm{~h}$ and $45 \mathrm{~min}$ in the temperate environment and $2 \mathrm{~h}$ during

Table 1. Physical characteristics of volunteers.

\begin{tabular}{c|c|c|c|c|c}
\hline $\mathbf{N}$ & $\begin{array}{c}\text { Age } \\
\text { (years) }\end{array}$ & $\begin{array}{c}\text { Body mass } \\
(\mathbf{k g})\end{array}$ & $\begin{array}{c}\text { Body height } \\
(\mathbf{c m})\end{array}$ & $\begin{array}{c}\text { Body fat } \\
(\%)\end{array}$ & $\begin{array}{c}\mathbf{V O}_{\text {2peak }} \\
\left(\mathbf{m L}_{\mathbf{k g}} \mathbf{~}^{-1} \cdot \mathbf{m i n}^{-1}\right)\end{array}$ \\
\hline 9 & $25.4 \pm 1.2$ & $80.9 \pm 2.4$ & $178.0 \pm 0.9$ & $15.7 \pm 1.6$ & $45.1 \pm 1.0$ \\
\hline
\end{tabular}


the two trials in the hot environment). Endurance exercise was performed inside an environmental chamber (Russells Inc. WWM-1150-5, USA) under the following conditions: 1) control trial in a temperate environment $\left(23^{\circ} \mathrm{C}\right.$ and $60 \% \mathrm{RH}$ ) (TEMP-C) with ingestion of a placebo solution, 2) a hot environment $\left(35^{\circ} \mathrm{C}\right.$ and $\left.60 \% \mathrm{RH}\right)$ with ingestion of a placebo solution (HOT-PLA) or (3) a hot environment with ingestion of a solution containing BCAA (HOT-BCAA). The experiments always began between 7:00 and 8:00 AM.

\section{Incremental test to determine peak oxygen consumption $\left(\mathrm{VO}_{2 \text { peak }}\right)$}

The incremental cycle ergometer test (Monark, Ergomedic 824-E, Sweden) was initiated at a power output of $50 \mathrm{~W}$ at $50 \mathrm{rpm}$, with 25-W increments every $2 \mathrm{~min}$. The criteria for interrupting the test were: an inability to maintain stipulated cadence, a score of 20 on the perceived exertion scale, ${ }^{16}$ a request made to stop exercise or the presence of pallor, cyanosis, or nausea. $\mathrm{VO}_{2 \text { PEAK }}$ was measured directly through a metabolic gas analyzer (BIOPAC Systems ${ }^{\circledR}$, GasSys2, USA, accuracy of \pm $1 \%$ for $\mathrm{O}_{2}$ and $\pm 3 \%$ for $\mathrm{CO}_{2}$ ).

\section{Force Task - isometric maximum voluntary contraction $\left(\mathrm{MVC}_{\mathrm{ISO}}\right)$}

The $\mathrm{MVC}_{\text {Iso }}$ test was performed to evaluate muscle strength. This test allows for monitoring of fatigue development during a sustained task of force production, avoiding compensatory movements, as the volunteer is kept in a standardized position.

Each volunteer performed 2-min $M_{V} C_{15 O}$ with the flexor muscles of the right elbow. While seated in a chair, adjusted to his height with feet resting on the ground, the volunteer had his position stabilized through straps wrapped around his trunk and thighs. The volunteer rested his arm on a metal plate, with a $90^{\circ}$ angle between the arm and the trunk, and a relative elbow angle of $90^{\circ}$. To minimize changes in position during the test, there was a $3-\mathrm{cm}$ high metal bulkhead where the elbow was supported throughout the test. The wrist, between $0^{\circ}$ and $30^{\circ}$ of extension, was stabilized through an orthosis. A band, wrapped in the volunteer's hand, was attached to a strain-sensitive force cell, against which the force was made. Each volunteer was instructed to perform at maximum force and received verbal stimuli, visual feedback of the force curve (without access to values) and elapsed time throughout the test. The data acquisition was performed using software (Dasylab ${ }^{\circledR} 5.0$ ) and an analog-digital converter (PCMCIA card) NIDAQ-700 at $1000 \mathrm{~Hz}$ (National Instruments ${ }^{\circledR}$, Austin, USA).

\section{Supplementation protocol}

The ingestion of the placebo (PLA) or BCAA solution, in a volume of $4.0 \mathrm{~mL} . \mathrm{kg}^{-1}$ body weight, ${ }_{17}^{17}$ occurred in a double-blind, crossed-over and randomized manner. The beverage was administered 120 and 60 min before, immediately before and every 30 min during the endurance exercise.

The PLA solution contained tangerine-flavored artificial juice, without calories or sugars ( $0 \%$ carbohydrate). The BCAA beverage was composed of the same PLA juice, with the addition of BCAA $\left(30 \mathrm{mg} \cdot \mathrm{kg}^{-1}\right.$ body mass - 54\% leucine, 27\% valine and 19\% isoleucine ${ }^{17}$ - AJINOMOTO Interamericana Ind. Com. Ltda.). The two drinks were matched in taste, color, aroma and temperature (12 to $\left.14^{\circ} \mathrm{C}\right)$.

\section{Experimental protocol}

The volunteers arrived at the laboratory after overnight fasting, ingested a dose of the solution corresponding to the experimental trial (i.e., PLA or BCAA) and a standardized breakfast (301 kcal; 78\% carbohydrates, 9\% protein and 13\% fat). After 30 min, the volunteers performed the pre-exercise $M \mathrm{MC}_{\mid \mathrm{SO}}$ test, the endurance exercise, and the post-exercise $\mathrm{MVC}_{150}$ test in sequence. The $\mathrm{MVC}_{\text {ISO }}$ tests were performed at room temperature between 22 and $24^{\circ} \mathrm{C}$. (Figure 1)

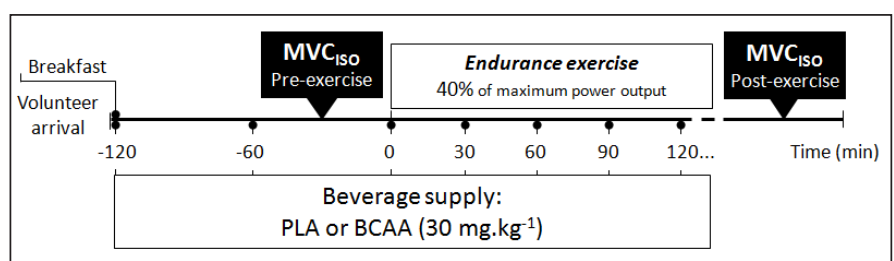

Figure 1. Experimental protocol.

During the $\mathrm{MVC}_{\text {ISO }}$ test, $\mathrm{T}_{\text {CORE }}$ and heart rate $(\mathrm{HR})$ were recorded. The $T_{\text {CORE }}$ was obtained every 30 s through a disposable rectal probe (Yellow Springs ${ }^{\circledR}, 4491-E$, USA) inserted $10 \mathrm{~cm}$ beyond the anal sphincter, connected to a telethermometer (Yellow Springs ${ }^{\circledR}$, YSI 4600 Series, USA). HR was measured by an HR monitor (Polar, S120 ${ }^{\circledR}$, Finland) every $15 \mathrm{~s}$.

\section{Statistical analyses}

Data were checked for normality using the Shapiro-Wilk test and, for this purpose, the data at the pre-exercise moment from each group were evaluated in isolation; all evaluated parameters presented a normal distribution. The homoscedasticity of the data was evaluated through Levene's tests, which confirmed the homogeneity of variances.

The data comparisons across time-points and between the different periods in the same experimental trial (Figure 2) or between the three trials (Figures 3 and 4) were performed using two-way ANOVAs with repeated measures and, when applicable (i.e., significant $F$ value), a post-hoc test was chosen according to the coefficient of variation (CV): Tukey ( $T_{\text {CORE }}$ and HR, CV $\leq 15 \%$ ) or Student Newman-Keuls (other variables, CV > 15\%). The Pearson correlation coefficient was used to assess the degree of association between the changes in $T_{\text {CORE }}$ and force. The significance level adopted was set at 0.05. Data were expressed as mean \pm standard error of the mean.

The Cohen's d effect size (ES) was calculated to assess the magnitude of differences in the data between experimental trials. The ES was calculated by subtracting the mean of a group (lower value) from the mean of a second group (higher value); the result was then divided by the pooled standard deviation of the data. As all volunteers were subjected to all experimental trials, ES was corrected by the Pearson coefficient obtained from the correlation between the values that were being compared. The ES values were classified as trivial ( $E S<0.2)$, small $(E S=0.2-0.6)$, moderate $(E S=0.6-1.2)$ or large $(E S \geq 1.2)^{18}$.

\section{RESULTS}

A decreased force of elbow flexors was observed, when compared to before the endurance exercise values, during the initial $15 \mathrm{~s}$ of the isometric test in TEMP-C (Figure 2A), over the $120 \mathrm{~s}$ in HOT-PLA (Figure 2B) and at 15, 30, and 60 to $120 \mathrm{~s}$ in HOT-BCAA (Figure 2C). Before the endurance exercise, the force was lower from the $30^{\text {th }}$ to the $60^{\text {th }} \mathrm{S}$ in the HOT-BCAA than in the HOT-PLA trial (Figure 2D).

Endurance exercise in the temperate environment did not reduce mean force (pre-exercise: $141.7 \pm 4.3 \mathrm{~N}$ vs. post-exercise: $137.7 \pm 7.0 \mathrm{~N}$; $P=0.30$; $E S=0.32$ ) (Figure 3) nor peak force $(P=0.09$; $E S=0.61)$ (Table 2); however, exercise in the hot environment led to a reduction in mean force for both the HOT-PLA (pre-exercise: 144.9 $\pm 6.8 \mathrm{~N}$ vs. post-exercise: $122.1 \pm 6.1 \mathrm{~N} ; P<0.001$; $\mathrm{ES}=2.22$ ) and HOT-BCAA (pre-exercise: $135.3 \pm 5.6 \mathrm{~N}$ vs. post-exercise: 118.6 $\pm 7.7 \mathrm{~N} ; P<0.001 ; E S=1.49$ ) trials (Figure 3 ); similar results were also observed for peak force. All of these reductions, caused by the exercise in a hot environment, were classified as large (Table 2). BCAA supplementation did not attenuate the reduction in mean force (HOT-PLA: $122.1 \pm 6.1 \mathrm{~N}$ vs. HOT-BCAA: $118.6 \pm 7.7 \mathrm{~N} ; P=0.37$; ES = 0.34) (Figure 3) or peak force (Table 2; ES =0.03) after endurance exercise 


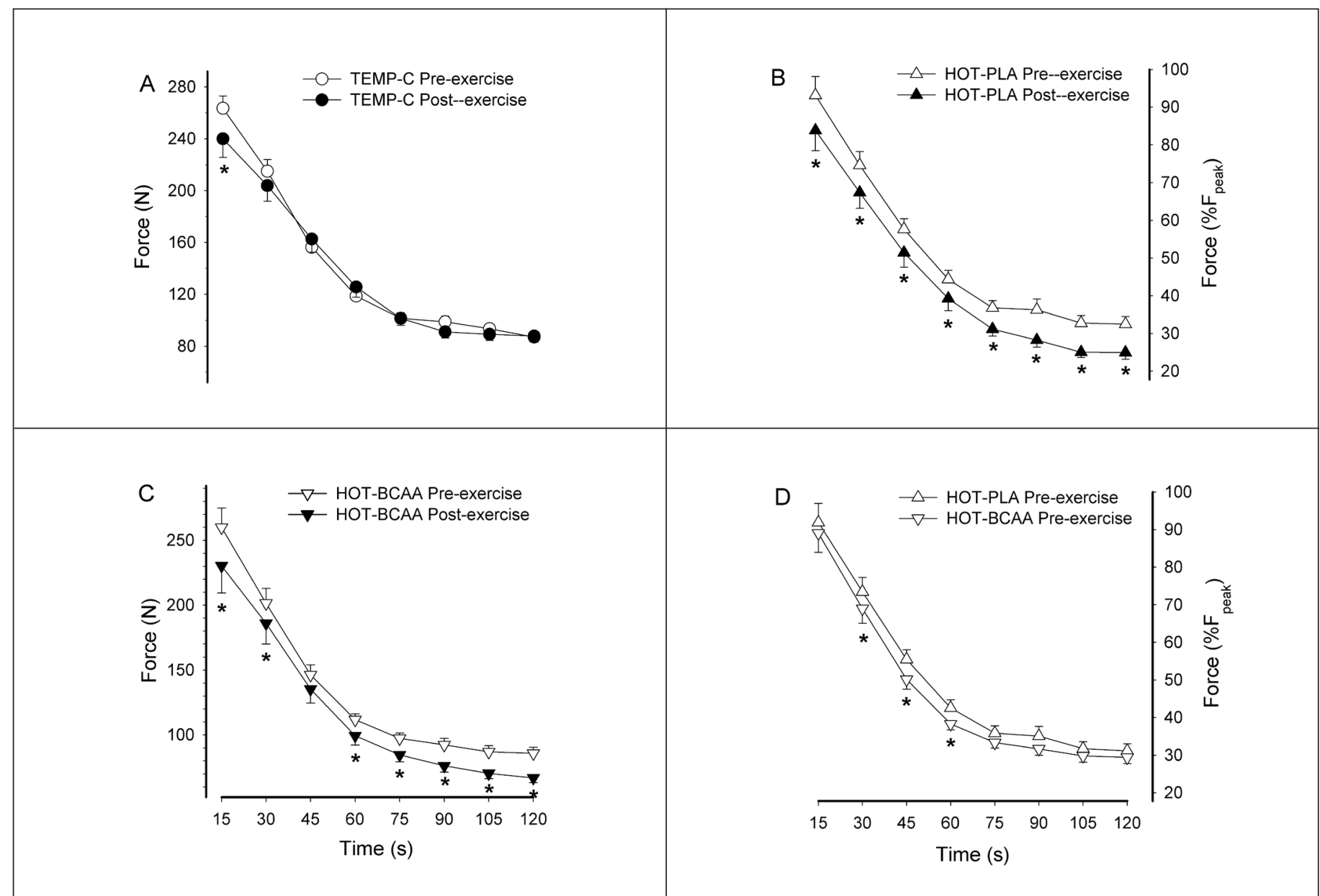

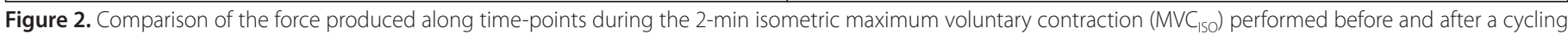

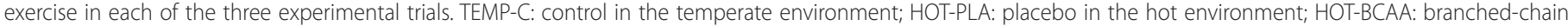
amino acids in the hot environment. Data are expressed as mean \pm SEM. ${ }^{*}$ Difference between experimental trials. $n=9$.

in the hot environment. The mean force measured during the $\mathrm{MVC}_{\mathrm{ISO}}$ pre-exercise was lower in the HOT-BCAA trial than in the HOT-PLA trial $(135.3 \pm 5.6 \mathrm{~N}$ vs. $144.9 \pm 6.8 \mathrm{~N} ; P=0.04 ; \mathrm{ES}=0.83)$, and tended to be significantly lower than in the TEMP-C trial $(P=0.09 ; \mathrm{ES}=0.73)$.

The $T_{\text {CORE }}$ and $H R$ values were not different between trials before the exercise. For all trials, the $T_{\text {CORE }}$ following the endurance exercise was higher when compared to values recorded before the exercise (TEMP-C: $+0.48^{\circ} \mathrm{C}, P=0.005$, ES $=1.18$; HOT-PLA: $+1.46^{\circ} \mathrm{C}$, $P<0.001, \mathrm{ES}=3.14$; $\mathrm{HOT}-\mathrm{BCAA}:+1.35^{\circ} \mathrm{C}, P<0.001$, $\mathrm{ES}=4.32$ ) (Figure 4). Following exercise, the $T_{\text {CORE }}$ values in the hot environment were higher than those found in the temperate environment $(P<0.001)$ (Figure 4), and supplementation with BCAA did not influence the increase in $T_{\text {CORE }}(P=0.57$; $E S=0.31)$. The change in $T_{\text {CORE }}$ correlated negatively with the change in force production $(r=-0.47$; $P=0.01)$ (Figure 5); that is, the increase in $T_{\text {CORE, }}$ induced by endurance exercise, was associated with reduced force production during the subsequent $\mathrm{MVC}_{\text {IsO }}$ test.

There was no difference in $\mathrm{HR}$ between $\mathrm{MVC}_{\text {ISO }}$ tests at pre- and post-endurance exercise in the TEMP-C trial (pre-exercise: $110 \pm 4 \mathrm{bpm}$ vs. post-exercise: $113 \pm 3 \mathrm{bpm} ; P=0.30 ; E S=0.22$ ). The HR was higher during the $\mathrm{MVC}_{\text {ISO }}$ test at post- than at pre-endurance exercise for both trials performed in the hot environment (HOT-PLA: +18 bpm, $P<0.001$, ES = 1.80; HOT-BCAA: +12 bpm, $P<0.001$, ES = 1.24) (Table 2) and as well higher at post-endurance exercise in the hot trials than in the TEMP-C trial $(P<0.01)$ (Table 2). However, when comparing the values between the two trials in the hot environment, supplementation with BCAA did not alter the $\mathrm{HR}(P=0.60$; $E S=0.21)$.

\section{DISCUSSION}

BCAA supplementation did not attenuate the reduction in isometric force caused by prior endurance exercise in a hot environment, thus not justifying the use of BCAA as an ergogenic aid during a concurrent training session, in which fatigue during the strength task is accentuated by body hyperthermia. The reduced post-endurance exercise force in the hot environment was accompanied by higher $T_{\text {CORE }}$ and HR values when compared to those recorded in the temperate environment. In addition, BCAA supplementation resulted in reduced force production during evaluation performed prior to endurance exercise.

One factor that may have supplanted the ergogenic effect of BCAA is the production of ammonia, a neurotoxic substance ${ }^{19}$ derived from the metabolism of these amino acids. ${ }^{20-23}$ This assumption may also explain the reduction in force during the pre-exercise $M V C_{150}$ in subjects supplemented with BCAA. Dong-Hee et al. (2013)22 showed a higher ammonia concentration at 40 min after the ingestion of a single dose of BCAA (80 mg. $\left.\mathrm{kg}^{-1}\right)$. MacLean, Graham and Saltin (1996) ${ }^{24}$ showed that high (308 $\mathrm{mg} \mathrm{kg}^{-1}$ ) and moderate $\left(77 \mathrm{mg} . \mathrm{kg}^{-1}\right.$ ) doses of BCAA, respectively, increased ammonia concentrations during $90 \mathrm{~min}$ and $60 \mathrm{~min}$ of a dynamic exercise involving knee extensors. However, hyperammonemia was not observed in other studies in which smaller amounts of BCAA were provided, 17,20,25 including the study of Mittleman et al. (1998), ${ }^{17}$ with a BCAA dose similar to the one used in the present study. Therefore, the relationship between the dose of BCAA and the reduction in isometric force, possibly due to hyperammonemia, should be better addressed in future studies. 


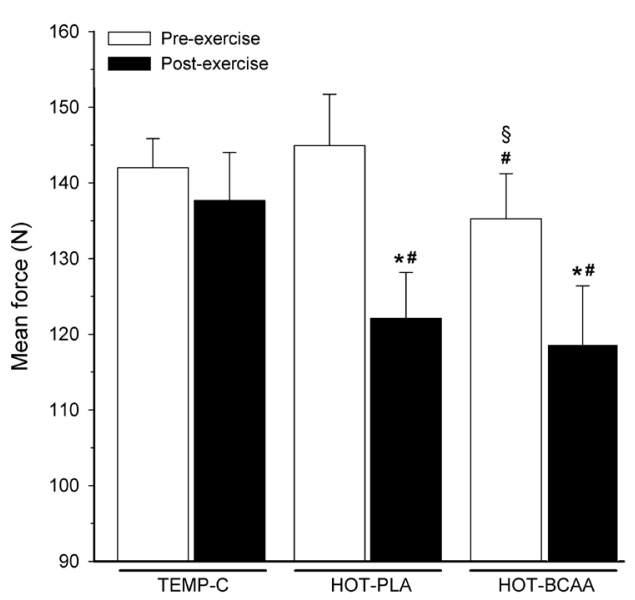

Figure 3. Mean values of the force produced during the 2-min isometric maximum voluntary contraction $\left(\mathrm{MVC}_{150}\right.$ ) performed before and after a cycling exercise in each of the three experimental trials. TEMP-C: control in the temperate environment; HOT-PLA: placebo in the hot environment; HOT-BCAA: branched-chain amino acids in the hot environment. Data are expressed as mean \pm SEM. * Different from the pre-exercise moment within the same experimental trial. \#Different from the TEMP-C trial at the same moment. §Different from the pre-exercise moment in the HOT-PLA trial. $n=9$

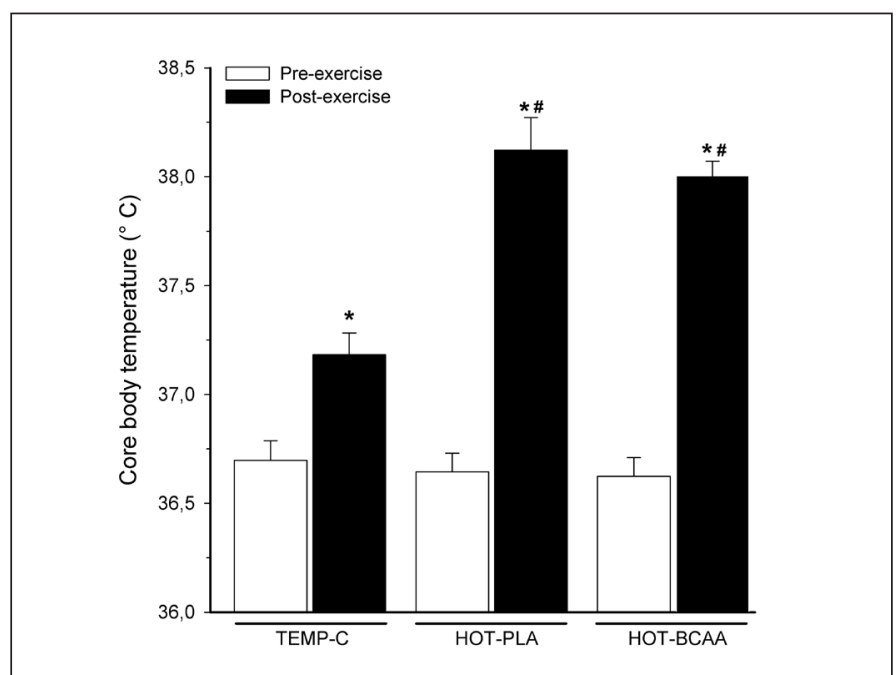

Figure 4. Mean core body temperature ( $\left.T_{\text {CORE }}\right)$ values during the 2-min isometric maximum voluntary contraction $\left(\mathrm{MVC}_{150}\right)$, performed before and after a cycling exercise in each of the three experimental trials. TEMP-C: control in the temperate environment; HOT-PLA: placebo in the hot environment; HOT-BCAA: branched-chain amino acids in the hot environment. Data are expressed as mean \pm SEM. ${ }^{*}$ Different from the pre-exercise moment within the same experimental trial. \#Different from the TEMP-C trial at the same time. $n=9$.

The present study reinforces the notion that a central component induces fatigue in concurrent exercises, ${ }^{5-7}$ as the lower force produced after the endurance exercise in the hot environment cannot be attributed to local factors derived from previous exercise performed with the same muscle group. Indeed, the muscle group tested during the MVC $\mathrm{MSO}_{150}$ was different from that which was exercised during the endurance exercise. Moreover, the reduction in force was not observed after the endurance exercise under temperate conditions. Thus, the results of this study contradict the position adopted by Raddi et al. (2008), ${ }_{1}^{26}$ who, after not observing the influence of a running protocol ( $45 \mathrm{~min}$ at $70 \% \mathrm{VO}_{2 \max }$ ) on force production, concluded that interference observed in the concurrent exercise is dependent on prior recruitment of the same muscle group.

The increase in $T_{\text {CORE }}$ determined a $22 \%$ reduction in isometric force at post-endurance exercise in the hot environment, as shown by the
Table 2. Heart rate $(H R)$ and peak force $\left(F_{\text {peak }}\right)$ values obtained during the 2-min maximal isometric voluntary contraction $\left(\mathrm{MVC}_{\mathrm{ISO}}\right)$, performed before and after a cycling exercise, in each of the three experimental trials.

\begin{tabular}{l|c|c|c|c|c|c|c|c|c}
\hline & \multicolumn{3}{|c|}{ TEMP-C } & \multicolumn{3}{c|}{ HOT-PLA } & \multicolumn{3}{c}{ HOT-BCAA } \\
\hline & $\begin{array}{c}\text { Pre- } \\
\text { exercise }\end{array}$ & $\begin{array}{c}\text { Post- } \\
\text { exercise }\end{array}$ & ES & $\begin{array}{c}\text { Pre- } \\
\text { exercise }\end{array}$ & $\begin{array}{c}\text { Post- } \\
\text { exercise }\end{array}$ & $\begin{array}{c}\text { Pre- } \\
\text { exercise }\end{array}$ & $\begin{array}{c}\text { Post- } \\
\text { exercise }\end{array}$ & ES \\
\hline $\mathrm{HR}(\mathrm{bpm})$ & $110 \pm 4$ & $113 \pm 4$ & 0.2 & $108 \pm 4$ & $127 \pm 4^{*}$ & 1.8 & $111 \pm 4$ & $122 \pm 3^{*}$ & 1.2 \\
\hline $\mathrm{F}_{\text {peak }}(\mathrm{N})$ & $292 \pm 14$ & $274 \pm 18^{*}$ & 0.6 & $293 \pm 13$ & $277 \pm 15^{*}$ & 1.5 & $294 \pm 16$ & $276 \pm 19^{*}$ & 0.5 \\
\hline $\begin{array}{l}\text { TEMP-C: control in the temperate environment; HOT-PLA: placebo in the hot environment; HOT-BCAA: bran- } \\
\text { ched-chain amino acids in the hot environment. * Different from the pre-exercise moment within the same } \\
\text { experimental trial. \# Different from the TEMP-C at the same time. } n=9 .\end{array}$
\end{tabular}

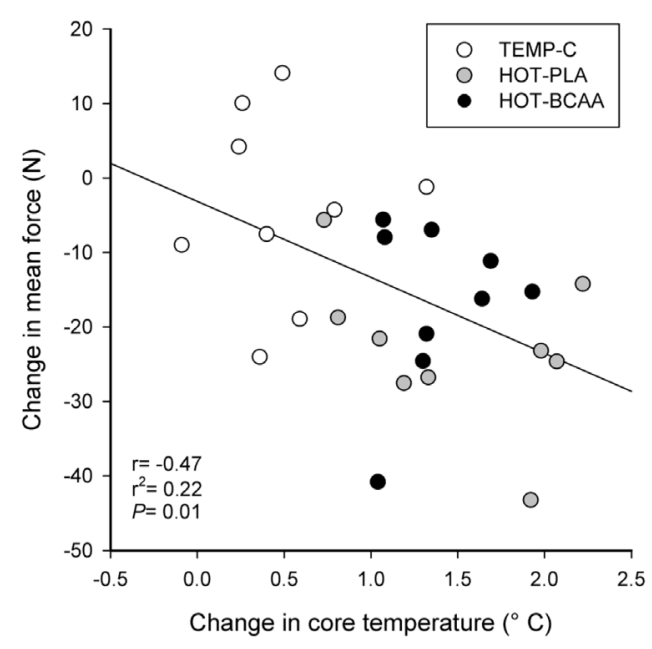

Figure 5. Correlation between the changes in core body temperature $\left(T_{\text {CORE }}\right)$ and the changes in mean force for the three experimental trials ( 27 points). TEMP-C: control in the temperate environment; HOT-PLA: placebo in the hot environment; HOT-BCAA: branched-chain amino acids in the hot environment.

correlation between these two variables, which corroborates the existence of an association between a rise in $T_{\text {CORE }}$ and a reduction in neuromuscular function, ${ }^{5}$ regardless of changes in muscle or skin temperature. ${ }^{6,7}$ Thus, it is likely that in the study of Raddi et al. (2008), ${ }_{1}^{26}$ the increase in T CORE was not great enough to reduce force - as is supported by our results obtained in the temperate environment. On the other hand, the study by Nybo and Nielsen $(2001)^{5}$ reported an 18\% force reduction in post-endurance exercise performed in a temperate environment; however, the $1.1^{\circ} \mathrm{C}$ temperature increase registered by the latter authors (from 36.9 to $38.0^{\circ} \mathrm{C}$ ) was higher than that observed in the present study $\left(0.46^{\circ} \mathrm{C}\right)$ and reinforces the relationship between the magnitude of the $T_{\text {CORE }}$ rise and the reduction in force. Thus, future experiments evaluating the isometric force during sustained tasks should consider the influence of the magnitude of the $T_{\text {CORE }}$ rise in reducing force production. Other factors may have also contributed to the lower strength performance associated with endurance exercise in a warm environment, such as central hypoglycemia, reduced cerebral blood flow caused by hyperventilation, endotoxemia and an increase in circulating pro-inflammatory cytokines. ${ }^{27}$

HR was higher during the post-exercise $M_{V} C_{150}$ in a hot environment, despite the reduction in force production. As this increase was not observed during the post-exercise $\mathrm{MVC}_{150}$ in the temperate environment, HR elevation appears to be a cardiovascular response driven by thermoregulatory stimuli to facilitate cutaneous heat dissipation while exercising in a hot environment.

The results of the present study, performed in a systematized and controlled manner, do not justify the use of a single dose of BCAA as an ergogenic aid for increasing muscle strength when individuals are hyperthermic. In addition, it is important to emphasize that, when prescribing high-intensity training, coaches should consider performing 
force exercises before endurance exercise, particularly when the latter exercise markedly elevates $T_{\text {CORE. }}$. Finally, additional studies are still needed to evaluate the effects of BCAA on force production during specific tests that reproduce sports skills.

\section{CONCLUSION}

The reduction in isometric force caused by endurance exercise in a hot environment was not diminished by acute BCAA supplementation.

\section{ACKNOWLEDGEMENTS}

The authors are grateful to CAPES, FAPEMIG, CNPq, PRPq-UFMG and the Programa de Apoio a Planos de Reestruturação e Expansão das Universidades Federais (REUNI) for the financial support and to Ajinomoto ${ }^{\circledR}$ do Brasil for supplying the BCAA.

All authors declare no potential conflict of interest related to this article

AUTHORS' CONTRIBUTIONS: Each author made significant individual contributions to this manuscript. MMM (0000-0003-4707-6099)*: intellectual concept of the research project and this article, data collection, statistical analysis, writing and revision of this article; RTPJ (in memoriam)*: intellectual concept of the research project and this article, data collection, and statistical analysis; FTC (0000-0001-5413-5718)*: intellectual concept of the research project, data collection, writing and revision of this article; GHCPC (0000-0002-7024-3505)* assistance in the design of equipment used during data collection, preparation of the worksheet for acquisition and analysis of force signals, and revision of this article; SPW (0000-00024659-1032)*: statistical analysis, writing and revision of this article; MHC (0000-0002-1955-8990)*: intellectual concept of the research project, assistance in the design of equipment used during data collection, and revision of this article. DDS (0000-0002-5705-8890)*: intellectual concept of the research project and this article, writing and revision of this article. *ORCID (Open Researcher and Contributor ID).

\section{REFERENCES}

1. Baar K. Using Molecular Biology to Maximize Concurrent Training. Sports Med. 2014;4(2):S117-25.

2. Aoki MS, Francisco LPJR, Navarro F, Uchida MC, Bacurau RFP. Suplementação de carboidrato não reverte o efeito deletério do exercício de endurance sobre o subsequente desempenho de força. Rev Bras Med Esporte. 2003;9(5):282-7.

3. Gomes RV, Aoki MS. Suplementação de creatina anula o efeito adverso do exercício de endurance sobre o subsequente desempenho de força. Rev Bras Med Esporte. 2003;11(2):131-4.

4. Painelli VS, Alves VT, Ugrinowitsch C, Benatti FB, Artioli GG, Lancha AH JR, et al. Creatine supplementation prevents acute strength loss induced by concurrent exercise. Eur J Appl Physiol. 2014;114(8):1749-55.

5. Nybo LE, Nielsen B. Hyperthermia and central fatigue during prolonged exercise in humans. J Appl Physiol. 2001;91(3):1055-60

6. Morrisson S, Sleivert GG, Cheung SS. Passive hipertermia reduces voluntary activation and isometric force production. Eur J Appl Physiol. 2004;91(5-6): 729-36.

7. Thomas MM, Cheung SS, Elder GC, Sleivert GG. Voluntary muscle activation is by core temperature rather than local muscle temperature. J Appl Physiol. 2006;100(4):1361-9.

8. Newsholme EA. Application of knowledge of metabolic integration to the problem of metabolic limitations in middle distance and marathon running. Acta Physiol Scand. 1986;128(556):93-7.

9. Davis JM, Bailey SP. Possible mechanisms of central nervous system fatigue during exercise. Med Sci Sports Exerc. 1997;29(1):45-57.

10. Meeusen R, Watson P, Hasegawa H, Roelands B, Piacentini MF. Central fatigue: the serotonin hypothesis and beyond. Sports Med. 2006;36(10):881-909

11. Meeusen R, Roelands B. Fatigue: Is it all neurochemistry? Eur J Sport Sci. 2018;18(1):37-46.

12. Davis JM, Alderson NL, Welsh RS. Serotonin and central nervous system fatigue: nutritional considerations. Am J Clin Nutr. 2000;72(2):573s-8s.

13. Soares DD, Coimbra CC, Marubayashi U. Tryptophan-induced central fatigue in exercising rats is related to serotonin content in preoptic area. Neurosci Lett. 2007;415(3):274-8.

14. Soares DD, Lima NR, Coimbra CC, Marubayashi U. Intracerebroventricular tryptophan increases heating and heat storage rate in exercising rats. Pharmacol Biochem Behav. 2004;78(2):255-61.
15. Garthe I, Maughan RJ. Athletes and Supplements: Prevalence and Perspectives. Int J Sport Nutr Exerc Metab. 2018;28(2):126-38.

16. Borg GA. Psychophysical bases of perceived exertion. Med Sci Sports Exerc. 1982;14(7):377-81.

17. Mittleman KD, Ricci MR, Bailey SP. Branched-chain amino acids prolong exercise during heat stress in men and women. Med Sci Sports Exerc. 1998;30(1):83-91.

18. Hopkins WG. A New View of Statistics, Sportcience. [Accessed 21 august 2017] [http://sportsci. org/resource/stats]. 2016.

19. Meeusen R, Watson P, Hasegawa H, Roelands B, Piacentini MF. Central fatigue: the serotonin hypothesis and beyond. Sports Med. 2006;36(10):881-909.

20. Strüder HK, Hollman W, Platen P, Donike M, Gotzmann A, Weber K. Influence of paroxetine, branched-chain amino acids and tyrosine on neuroendocrine system responses and fatigue in humans. Horm Metab Res. 1998;30(4):188-94.

21. Madsen K, Maclean DA, Kiens B, Christensen D. Effects of glucose, glucose plus branched-chain amino acids, or placebo on bike performance over $100 \mathrm{~km}$. J Appl Physiol. 1996;81(6):2644-50

22. Dong-Hee K, Seok-Hwan K, Woo-Seok J, Ha-Yan L. Effect of BCAA intake during endurance exercises on fatigue substances, muscle damage substances, and energy metabolism substances. J Exerc Nutrition Biochem. 2013;17(4):169-80.

23. Mikulski T, Dabrowski J, Hilgier W, Ziemba A, Krzeminski K. Effects of supplementation with branched chain amino acids and ornithine aspartate on plasma ammonia and central fatigue during exercise in healthy men. Folia Neuropathol. 2015;53(4):377-86.

24. MacLean DA, Graham TE, Saltin B. Branched-chain amino acids augment ammonia metabolism while attenuating protein breakdown during exercise. Am J Physiol. 1994;267(6 Pt 1):E1010-22.

25. Varnier M, Sarto P, Martines D, Lora L, Carmignoto F, Leese GP, et al. Effect of infusing branched-chain amino acid during incremental exercise with reduced muscle glycogen content. Eur J Appl Physiol Occup Physiol. 1994;69(1):26-31

26. Raddi LLO, Gomes RV, Charro MA, Bacurau RFP, Aoki MS. Treino de corrida não interfere no desempenho de força de membros superiores. Rev Bras Med Esporte. 2008;14(6):544-7.

27. Cheung SS, Sleivert GG. Multiple triggers for hyperthermic fatigue and exhaustion. Exerc Sport Sci Rev. 2004;32(3):100-6. 